Pacific Journal of Mathematic 


\title{
AVERAGES OF FOURIER COEFFICIENTS
}

\author{
RICHARD R. GOLDBERG
}

We shall say the sequence $a_{n}(n=1,2, \cdots)$ is a $p$-sequence $(1 \leqq p<\infty)$ if there is a function $f \in L^{p}(0, \pi)$ such that

$$
a_{n}=\int_{0}^{\pi} f(t) \cos n t d t \quad n=1,2, \cdots ;
$$

(i.e. the $a_{n}$ are Fourier cosine coefficients of an $L^{p}$ function).

A famous theorem of Hardy [1] states that if $a_{n}$ is a $p$-sequence $(1 \leqq p<\infty)$ and $b_{n}=\frac{1}{n}\left(a_{1}+a_{2}+\cdots+a_{n}\right)$, then $b_{n}$ is also a $p$-sequence.

In this paper we shall prove the following generalization of Hardy's theorem:

THEOREM 1. Let $\psi(x)$ be of bounded variation on $0 \leqq x \leqq 1$, and let $1 \leqq p<\infty$. Then, if $a_{n}$ is a p-sequence and

$$
b_{n}=\frac{1}{n} \sum_{m=1}^{n} \psi\left(\frac{m}{n}\right) a_{m},
$$

$b_{n}$ is also a p-sequence.

Hardy's theorem is the special case $\psi(x)=1$ for $0 \leqq x \leqq 1$.

If the conclusion of Theorem 1 holds for each of two functions $\psi$ it clearly holds for their difference. Hence it is sufficient to prove Theorem 1 in the case where $\psi(x)$ is non-decreasing for $0 \leqq x \leqq 1$. Further, since any non-decreasing function may be written as the difference of two non-negative non-decreasing functions (the second of which is constant) to prove Theorem 1 it is sufficient to prove

THEOREM 1A. Let $\psi(x)$ be non-negative and non-decreasing on $0 \leqq x \leqq 1$ and let $1 \leqq p<\infty$. Then, if $a_{n}$ is a $p$-sequence and

$$
b_{n}=\frac{1}{n} \sum_{m=1}^{n} \psi\left(\frac{m}{n}\right) a_{m},
$$

$b_{n}$ is also a p-sequence.

The proof of Theorem 1A will follow a sequence of lemmas.

Lemma 1. Let $B_{t}(x)=\int_{0}^{x} \cos y t d(y-[y])$. Then there is an $M>0$

Received February 24, 1959. This research was supported in part by the United States Air Force under Contract No. AF 49 (638)-383 monitored by the AF Office of Scientific Research of the Air Research and Development Command. 
such that

$$
\left|B_{t}(x)\right| \leqq M \quad 0 \leqq t \leqq \pi ; 0 \leqq x<\infty .
$$

The symbol $[y]$ denotes the greatest integer not exceeding $y$.

Proof. Let $n$ be any non-negative integer. Then for $t>0$

$$
\int_{0}^{n} \cos y t d y=\frac{\sin n t}{t}
$$

and

$$
\int_{0}^{n} \cos y t d[y]=\sum_{m=1}^{n} \cos m t=\frac{\sin (n+1 / 2) t}{2 \sin t / 2}-\frac{1}{2} .
$$

Hence

$$
\begin{aligned}
B_{t}(n) & =\frac{\sin n t}{t}-\frac{\sin (n+1 / 2) t}{2 \sin t / 2}+\frac{1}{2} \\
& =\sin n t\left(\frac{1}{t}-\frac{1}{2} \cot \frac{t}{2}\right)-\frac{\cos n t}{2}+\frac{1}{2}
\end{aligned}
$$

and so

$$
\left|B_{t}(n)\right| \leqq\left|\frac{1}{t}-\frac{1}{2} \cot \frac{t}{2}\right|+1 \quad n=0,1,2, \cdots
$$

The right side of (1) is bounded for $0<t \leqq \pi$. Thus for some $M \geqq 1$

$$
\left|B_{t}(n)\right| \leqq M-1 \quad n=0,1,2, \cdots ; 0<t \leqq \pi .
$$

Now take any $x \geqq 0$ and let $n=[x]$. Then

$$
B_{t}(x)=B_{t}(n)+\int_{n}^{x} \cos y t d(y-[y])
$$

so that from (2) we have for any $x \geqq 0$

$$
\left|B_{t}(x)\right| \leqq M-1+\int_{n}^{x}|d(y-[y])| \leqq M-1+x-n \leqq M, 0<t \leqq \pi
$$

and the proof is complete since $B_{0}(x): x-[x] \leqq 1 \leqq M$.

(Henceforth we assume $\psi(x) \geqq 0$ and $\psi(x)$ non-decreasing for $0 \leqq x \leqq 1$.)

Lemma 2. There is an $M>0$ such that

$$
\left|\int_{0}^{n} \psi\left(\frac{x}{n}\right) \cos x t d(x-[x])\right| \leqq M \quad 0 \leqq t \leqq \pi ; n=1,2, \cdots
$$

Proof. With $B_{t}(x)$ as in Lemma 1 we have 


$$
\begin{gathered}
\int_{0}^{n} \psi\left(\frac{x}{n}\right) \cos x t d(x-[x])=\int_{0}^{n} \psi\left(\frac{x}{n}\right) d B_{t}(x) \\
=\psi(1) B_{t}(n)-\int_{0}^{n} B_{t}(x) d \psi\left(\frac{x}{n}\right) .
\end{gathered}
$$

Thus with $M$ as in Lemma 1

$$
\left|\int_{0}^{n} \psi\left(\frac{x}{n}\right) \cos x t d(x-[x])\right| \leqq M \psi(1)+M \int_{0}^{n} d \psi\left(\frac{x}{n}\right) \leqq 2 M \psi(1),
$$

and the lemma is prove (with $2 M \psi(1)$ instead of $M$ ).

Lemma 3. Let $f \in L^{\prime}(0, \pi)$ and let

$$
d_{n}=\frac{1}{n} \int_{0}^{\pi} f(t) d t \int_{0}^{n} \psi\left(\frac{x}{n}\right) \cos x t d(x-[x]) \quad n=1,2, \cdots
$$

Then

$$
d_{n}=O\left(\frac{1}{n}\right)
$$$$
n \rightarrow \infty
$$

and hence $d_{n}$ is a p-sequence for every $p \geqq 1$.

Proof. By Lemma 2 there is an $M>0$ such that $\left|d_{n}\right| \leqq \frac{M}{n} \int_{0}^{\pi}|f(t)| d t$ from which (3) follows. From (3) it follows that $\sum_{n=1}^{\infty}\left|d_{n}\right|^{\alpha}<\infty$, for every $q>1$. By the Hausdorff-Young theorem and the fact that $L^{p} \leqq L^{p^{\prime}}$ if $1 \leqq p^{\prime} \leqq p$, this implies that $d_{n}$ is a $p$-sequence for every $p \geqq 1$. (See [2].)

From now on we shall write $f \sim a_{n}$ as an abbreviation for $a_{n}=\int_{0}^{\pi} f(t) \cos n t d t, n=1,2, \cdots$.

Lemma 4. Let $1 \leqq p<\infty, f \in L^{p}(0, \pi)$ and $a(x)=\int_{0}^{\pi} f(t) \cos x t d t$ so that

$$
f \sim a_{n}=a(n)
$$

Let

$$
g(x)=\int_{x}^{\pi} \frac{1}{t} \psi\left(\frac{x}{t}\right) f(t) d t \quad c_{n}=\frac{1}{n} \int_{0}^{n} \psi\left(\frac{x}{n}\right) a(x) d x .
$$

Then $g \in L^{p}(0, \pi)$ and

$$
g \sim c_{n} .
$$

Proof. Since $|g(x)| \leqq \psi(1) \int_{x}^{\pi} \frac{|f(t)|}{t} d t$ it follows from the proof in [1] that $g \in L^{p}$. Also 


$$
\begin{aligned}
& \int_{0}^{\pi} g(x) \cos n x d x=\int_{0}^{\pi} \cos n x d x \int_{x}^{\pi} \frac{1}{t} \psi\left(\frac{x}{t}\right) f(t) d t \\
& =\int_{0}^{\pi} \frac{1}{t} f(t) d t \int_{0}^{t} \psi\left(\frac{x}{t}\right) \cos n x d x=\int_{0}^{\pi} f(t) d t \int_{0}^{1} \psi(x) \cos n x t d t \\
& =\frac{1}{n} \int_{0}^{\pi} f(t) d t \int_{0}^{n} \psi\left(\frac{x}{n}\right) \cos x t d t=\frac{1}{n} \int_{0}^{n} \psi\left(\frac{x}{n}\right) \int_{0}^{\pi} f(t) \cos x t d t=c_{n} .
\end{aligned}
$$

The changes in order of integration are valid since

$$
\int_{0}^{\pi}|f(t)| d t \int_{0}^{1}|\psi(x) \cos n x t| d x \leqq \psi(1) \int_{0}^{\pi}|f(t)| d t<\infty .
$$

(Note $f \in L^{\prime}(0, \pi)$ since $f \in L^{p}(0, \pi)$.) Thus $g \sim c_{n}$, which is what we wished to show.

We can now establish our principal result.

Proof of Theorem 1A. Let $f \in L^{p}(0, \pi)$ be such that $f \sim a_{n}$ and let $a(x), g(x), c_{n}$ be as in Lemma 4 . Then

$$
b_{n}=\frac{1}{n} \sum_{m=1}^{n} \psi\left(\frac{m}{n}\right) a_{m}=\frac{1}{n} \int_{0}^{n} \psi\left(\frac{x}{n}\right) a(x) d[x]
$$

so that

$$
\begin{gathered}
c_{n}-b_{n}=\frac{1}{n} \int_{0}^{n} \psi\left(\frac{x}{n}\right) a(x) d(x-[x])=\frac{1}{n} \int_{0}^{n} \psi\left(\frac{x}{n}\right) d(x-[x]) \int_{0}^{\pi} f(t) \cos x t d t \\
=\frac{1}{n} \int_{0}^{\pi} f(t) d t \int_{0}^{n} \psi\left(\frac{x}{n}\right) \cos x t d(x-[x]) .
\end{gathered}
$$

The last iterated integral clearly converges absolutely, justifying the change in order of integration. By Lemma $3 c_{n}-b_{n}$ is a $p$-sequence. Also $c_{n}$ is a $p$-sequence since, by Lemma $4, g \in L^{p}(0, \pi)$ and $g \sim c_{n}$. Hence $b_{n}=c_{n}-\left(c_{n}-b_{n}\right)$ is a $p$-sequence and the theorem is proved.

REMARK. Note that except for the result of Lemma 1 the only properties of the cosine function used were its boundedness and the fact that $O\left(\frac{1}{n}\right)$ is a $p$-sequence for all $p \geqq 1$.

Lemma 5. Let $C_{t}(x)=\int_{0}^{x} \sin y t d(y-[y])$. Then there is an $M>0$ such that

$$
\left|C_{t}(x)\right| \leqq M \quad 0 \leqq t \leqq \pi ; 0 \leqq x<\infty
$$

Proof: Let $n$ be any non-negative integer. Then for $t>0$ 


$$
\int_{0}^{n} \sin y t d y=\frac{1}{t}-\frac{\cos n t}{t}
$$

and

$$
\int_{0}^{n} \sin y t d[y]=\sum_{k=1}^{n} \sin k t=\frac{\cos t / 2-\cos (n+1 / 2) t}{2 \sin t / 2}
$$

Hence

$$
\begin{gathered}
C_{t}(n)=\frac{1}{t}-\frac{\cos n t}{t}-\frac{\cos t / 2-\cos (n+1 / 2) t}{2 \sin t / 2} \\
=(1-\cos n t)\left(\frac{1}{t}-\frac{1}{2} \cot \frac{t}{2}\right)-\frac{\sin n t}{2} .
\end{gathered}
$$

The remainder of the proof follows as in Lemma 1.

In view of Lemma 5 and the remark preceding it the exact analogue of Theorem 1 for sine coefficients must hold. This we now state:

Theorem 2. Fix $p \geqq 1$. If, for some $f \in L^{p}$,

$$
a_{n}=\int_{0}^{\pi} f(t) \sin n t d t \quad n=1,2, \cdots,
$$

and if $b_{n}=\frac{1}{n} \sum_{m=1}^{n} \psi\left(\frac{m}{n}\right) a_{m}$ where $\psi(x)$ is of bounded variation on $0 \leqq x \leqq 1$ then there exists $g \in L^{p}$ such that

$$
b_{n}=\int_{0}^{\pi} g(t) \sin n t d t \quad n=12, \cdots
$$

\section{REFERENCES}

1. G. H. Hardy, Notes on some points in the integral calculus, Messenger of Mathematics 58 (1929), 50-52.

2. A. Zygmund, Trigonometrical Series, Warsaw 1935 p. 190.

NoRThWESTERN UNIVERSITY 



\section{PACIFIC JOURNAL OF MATHEMATICS}

\section{EDITORS}

\section{David Gilbarg}

Stanford University Stanford, California

\section{R. A. Beaumont}

University of Washington

Seattle 5, Washington

\section{A. L. Whiteman}

University of Southern California Los Angeles 7, California

L. J. Paige

University of California

Los Angeles 24, California

\section{ASSOCIATE EDITORS}

E. F. BECKENBACH
C. E. BURGESS
E. HEWITT
A. HORN

A. HORN

\author{
V. GANAPATHY IYER \\ R. D. JAMES \\ M. S. KNEBELMAN \\ L. NACHBIN
}

I. NIVEN

T. G. OSTROM

H. L. ROYDEN

M. M. SCHIFFER
E. G. STRAUS

G. SZEKERES

F. WOLF

K. YOSIDA

\section{SUPPORTING INSTITUTIONS}

\author{
UNIVERSITY OF BRITISH COLUMBIA \\ CALIFORNIA INSTITUTE OF TECHNOLOGY \\ UNIVERSITY OF CALIFORNIA \\ MONTANA STATE UNIVERSITY \\ UNIVERSITY OF NEVADA \\ OREGON STATE COLLEGE \\ UNIVERSITY OF OREGON \\ OSAKA UNIVERSITY \\ UNIVERSITY OF SOUTHERN CALIFORNIA
}

\author{
STANFORD UNIVERSITY \\ UNIVERSITY OF TOKYO \\ UNIVERSITY OF UTAH \\ WASHINGTON STATE COLLEGE \\ UNIVERSITY OF WASHINGTON \\ * * * * \\ AMERICAN MATHEMATICAL SOCIETY \\ CALIFORNIA RESEARCH CORPORATION \\ HUGHES AIRCRAFT COMPANY \\ SPACE TECHNOLOGY LABORATORIES
}

Mathematical papers intended for publication in the Pacific Journal of Mathematics should be typewritten (double spaced), and the author should keep a complete copy. Manuscripts may be sent to any one of the four editors. All other communications to the editors should be addressed to the managing editor, L. J. Paige at the University of California, Los Angeles 24, California.

50 reprints per author of each article are furnished free of charge; additional copies may be obtained at cost in multiples of 50 .

The Pacific Journal of Mathematics is published quarterly, in March, June, September, and December. The price per volume (4 numbers) is $\$ 12.00$; single issues, $\$ 3.50$. Back numbers are available. Special price to individual faculty members of supporting institutions and to individual members of the American Mathematical Society: $\$ 4.00$ per volume; single issues, $\$ 1.25$.

Subscriptions, orders for back numbers, and changes of address should be sent to Pacific Journal of Mathematics, 2120 Oxford Street, Berkeley 4, California.

Printed at Kokusai Bunken Insatsusha (International Academic Printing Co., Ltd.), No. 6, 2-chome, Fujimi-cho, Chiyoda-ku, Tokyo, Japan.

PUBLISHED BY PACIFIC IOURNAL OF MATHEMATICS, A NON-PROFIT CORPORATION

The Supporting Institutions listed above contribute to the cost of publication of this Journal, but they are not owners or publishers and have no responsibility for its content or policies. 


\section{Pacific Journal of Mathematics}

\section{Vol. 9, No. $3 \quad$ July, 1959}

Errett Albert Bishop, A minimal boundary for function algebras . . . . . . . . . . . . 629

John W. Brace, The topology of almost uniform convergence . . . . . . . . . . . . 643

Cecil Edmund Burgess, Chainable continua and indecomposability .......... 653

L. Carlitz, Multiplication formulas for products of Bernoulli and Euler

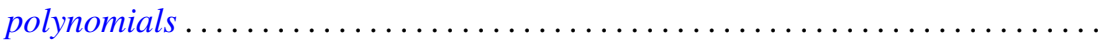

Eckford Cohen, A class of residue systems (mod $r$ ) and related arithmetical

functions. II. Higher dimensional analogues ....................

Shaul Foguel, Boolean algebras of projections of finite multiplicity . . . . . . . . . .

Richard Robinson Goldberg, Averages of Fourier coefficients .................

Seymour Goldberg, Ranges and inverses of perturbed linear operators .

Philip Hartman, On functions representable as a difference of convex functions ....

Milton Vernon Johns, Jr. and Ronald Pyke, On conditional expectation and

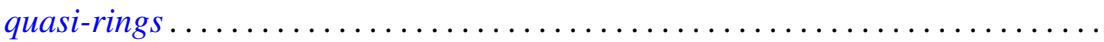

Robert Jacob Koch, Arcs in partially ordered spaces ....................

Gregers Louis Krabbe, A space of multipliers of type $L^{p}(-\infty, \infty) \ldots \ldots \ldots \ldots$

John W. Lamperti and Patrick Colonel Suppes, Chains of infinite order and their

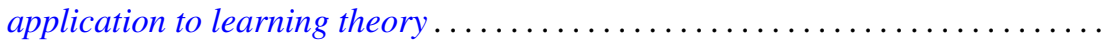

Edith Hirsch Luchins, On radicals and continuity of homomorphisms into Banach

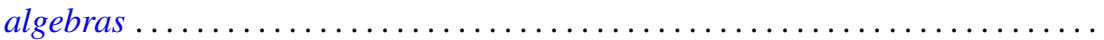

T. M. MacRobert, Multiplication formulae for the E-functions functions of their parameters.

Michael Bahir Maschler, Classes of minimal and representative domains and their kernel functions.

William Schumacher Massey, On the imbeddability of the real projective spaces in Euclidean space.

Thomas Wilson Mullikin, Semi-groups of class $\left(C_{0}\right)$ in $L_{p}$ determined by parabolic differential equations

Steven Orey, Recurrent Markov chains

Ernest Tilden Parker, On quadruply transitive groups ........ . .

Calvin R. Putnam, On Toeplitz matrices, absolute continuity, and unitary

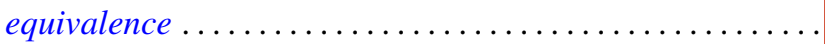

Helmut Heinrich Schaefer, On nonlinear positive operators.

Robert Seall and Marion Wetzel, Some connections between continued fractions and convex sets

Robert Steinberg, Variations on a theme of Chevalley

Olga Taussky and Hans Zassenhaus, On the similarity transformation between a

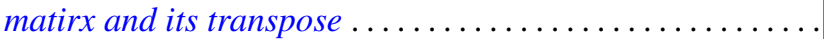

Emery Thomas, The suspension of the generalized Pontrjagin cohomology

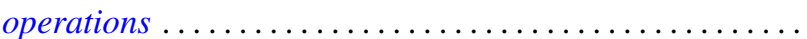

Joseph L. Ullman, On Tchebycheff polynomials ..................... 913

Richard Steven Varga, Orderings of the successive overrelaxation scheme ........ 925

Orlando Eugenio Villamayor, Sr., On weak dimension of algebras . 